RESIDENT

\& FELLOW

SECTION

Section Editor

Mitchell S.V. Elkind,

MD, MS

\title{
Emerging Subspecialties in Neurology: Neuroinfectious diseases
}

John J. Millichap, MD

Leon G. Epstein, MD

Address correspondence and reprint requests to Dr. John J. Millichap, Division of Neurology, Children's Memorial Hospital, 2300 Children's Plaza, Box 51, Chicago, IL 60614

jmillichap@childrensmemorial.org
Infection as a cause of neurologic disease is a prominent feature in the history of medicine. The training of the practitioner called to care for these patients has changed throughout the years. To understand the history of infectious disease in neurologic practice, consider the relative infancy of the specialty of neurology in the United States. Neurology as an independent specialty board did not emerge from the cloak of neuropsychiatry and internal medicine until after World War II and the founding of the American Academy of Neurology (AAN). Neuropathology was an integral part of the curriculum, and neuroinfectious diseases were taught primarily from the pathologic perspective. In 1964, H. Merritt $^{1}$ thought infectious disease was sufficiently important to be the subject of the first chapter in the third edition of his Textbook of Neurology. The increasing importance of infectious disease in neurology is evident from the more recent publication of dedicated textbooks on both pediatric and general neuroinfectious disorders. $^{2-4}$

Early practitioners in the field of neurology were first recognized for their work with neuroinfections. A major purpose of the Pasteur institute that opened in Paris in 1888 was to care for the multitude of patients with rabies. $^{5}$ In the same year, the first neurologist at Johns Hopkins' was noted to be involved in the treatment of tabes dorsalis. ${ }^{6}$ The 20th century saw several infectious diseases of epidemic proportions with significant neurologic sequelae. In 1917, Constantin von Economo described encephalitis lethargica related to the influenza epidemic. ${ }^{1}$ Anterior poliomyelitis was widespread in the 1940s-1950s. Complications of these diseases that required long-term neurologic care included postencephalitic parkinsonism and postpolio syndrome. ${ }^{1}$ AIDS, the present-day epidemic, has complications such as HIV-associated dementia studied by neurologists since the 1980s. ${ }^{7}$

Nonepidemic viral infections constitute the majority of infections affecting the nervous system today. ${ }^{8}$ Chronic neurologic disease as a sequel to infection is a relatively new and developing area of both pediatric and adult neurology research. Chief among these disorders is the role of postinfectious brain inflammation in epileptogenesis.?

In addition to nonepidemic viral infections, modern neurologists with expertise in infectious diseases care for patients with a variety of infections and their sequelae in multiple clinical settings. Acute CNS infection may require intensive care for the management of increased intracranial pressure and status epilepticus. ${ }^{4}$ Immunosuppression for cancer, organ transplant, and autoimmune disorders increases the number of patients at risk for opportunistic neuroinfections. ${ }^{8,10}$ Patients with HIV may develop lymphoma and neuropathy. Other conditions with infectious associations include prion and autoimmune disorders. ${ }^{4}$

TRAINING OPPORTUNITIES IN NEUROINFECTIOUS DISEASES During the 2008 meeting of the AAN Section on Neuroinfectious Diseases (aan.com/ go/about/sections/disease), a proposal was voted forward to develop a subspecialty fellowship accredited by the United Council for Neurological Subspecialties (UCNS). The UCNS currently accredits many emerging subspecialties including neurocritical care and headache (ucns.org). Board certification in both neurology and infectious disease is not a practical route for most subspecialists in the field. However, this option may be possible for child neurologists. Since most obtain board certification in pediatrics, they would then be eligible for conventional fellowships in pediatric infectious diseases after completion of neurology training.

Non-accredited subspecialty fellowship training is currently available in this field at several institutions. Representative programs were located by Internet search of university Web sites and are listed in the table. The amount of time devoted to research and clinical varies between centers, and some institutions focus only on AIDS or virology. Interested trainees may also acquire expertise in infectious diseases in a neurology program active in research or closely associated with an established infectious disease service. Subspecialists practicing neuroinfectious diseases also 
Table Representative neuroinfectious diseases fellowships for neurologists

Institution

Johns Hopkins Division

of Neuroimmunology \&

Infectious Diseases,

Clinical Fellowship

Massachusetts General

Hospital, Advanced

General Neurology Fellowship

UCSF Department of

Neurology, Neuro-AIDS
Clinical Research Fellowship

$\begin{array}{ll}\begin{array}{l}\text { Program director(s) } \\ \text { Justin McArthur, MD }\end{array} & \text { Web site } \\ & \begin{array}{l}\text { www.neuro.jhmi.edu/ } \\ \text { nrolD/jobs.htm }\end{array} \\ \text { Gopal Venna, MD } & \begin{array}{l}\text { http://www.partners.org/ } \\ \text { research/gme/research_ } \\ \text { gme_mgh.html }\end{array} \\ \begin{array}{l}\text { Richard Price, MD; } \\ \text { Cheryl Jay, MD; and } \\ \text { Serena Spudich, MD }\end{array} & \begin{array}{l}\text { neurology.ucsf.edu/brain/ } \\ \text { research.htm }\end{array}\end{array}$

Representative programs were located by Internet search of university Web sites.

list training in neurovirology at NIH in Bethesda, $\mathrm{MD}$, and in neuroinfectious diseases at Indiana University in Indianapolis. Successful training in neuroinfectious diseases, as in other specialties, requires a close identification with a mentor in the field.

CAREER PROSPECTS IN NEUROINFECTIOUS DISEASES Since accredited fellowships are still in the developing stage, entry to this field may take many forms. A career in this subspecialty would necessarily be located in a university affiliated hospital or large neurology clinic, with opportunities for clinical or basic laboratory research. A position in an established practice is preferable to creating a niche in this area at a local facility. The latter may be plausible for an individual in the form of an intermittent specialty clinic in addition to general practice. A search of the AAN directory provides a list of approximately 90 members of the Section on Neuroinfectious Diseases (aan.com/go/about/sections/ disease). In addition to the list of institutions in the table, Indiana University in Indianapolis (http://neurology. medicine.iu.edu/body.cfm? $\mathrm{id}=3078 \&$ oTopID $=$ 3022), Mayo Clinic in Rochester, MN (mayoclinic. org/neurology-rst/neuroid.html), and the University of Kentucky in Lexington (ukhealthcare.uky.edu/ $\mathrm{KNI} /$ clinic_infectious.htm) also advertise specialist clinics in neuroinfectious diseases. A list of practitioners with expertise in neuro-AIDS is available on The Neurologic AIDS Research Consortium (NARC) Web site (narc.wustl.edu/narc/default.aspx).

A neuroinfectious disease specialist in a hospital or clinic would act as consultant to the infectious disease service, especially for acute presentations and complications. Another important role for the neuroinfectious disease specialist is the diagnosis and management of chronic neuroinfectious disorders, including postinfectious epilepsy. ${ }^{8,9}$ New diagnostic tools using molecular methods and the development of new antimicrobial and antiinflammatory agents is an important area of future research. Membership and active participation in the AAN Section on Neuroinfectious Disease and the Infectious Diseases Society of America (idsociety.org) is vital to career development.

DISCUSSION The development of neuroinfectious diseases as a subspecialty is essential for the care of large numbers of patients already affected by today's most important pathogens and to prepare for tomorrow's. ${ }^{6,8}$ Collaboration with internal medicine- or pediatrics-based infectious diseases specialists is an important part of this practice. ${ }^{10}$ Despite the long history of infections affecting the nervous system, the prospect of a formal subspecialty fellowship and certification combining these 2 fields remains a work in progress. Neurologists have the unique understanding of this complex organ system and how certain infections may cause damage. As more neuropathogens emerge, medicine will need more neurologists with subspecialty training, experience, and interest in infectious disorders to develop new diagnostic, preventative, and therapeutic options for these patients. ${ }^{6}$

\section{DISCLOSURE}

Leon G. Epstein receives research support from the NIH [R01-NS43209 and 1UL1RR025741-01]. John J. Millichap reports no disclosures.

\section{REFERENCES}

1. Merritt HH. A Textbook of Neurology, 3rd ed. Philadelphia: Lea \& Febiger; 1964.

2. Barton LL, Friedman NR, eds. The Neurological Manifestations of Pediatric Infectious Diseases and Immunodeficiency Syndromes. Totowa, NJ: Humana Press; 2008.

3. Johnson RT. Viral Infections of the Nervous System. Philadelphia: Lippincott Williams \& Wilkins; 1982.

4. Roos KL, ed. Principles of Neurologic Infectious Diseases: Principles and Practice. New York: McGraw-Hill; 2004.

5. Neuroinfections: celebrating the past, discussing the present. Lancet Neurol 2008;7:975.

6. Griffin JW. Neurologists don't do windows. Nat Clin Pract Neurol 2006;2:1.

7. Epstein LG, Sharer LR, Cho ES, Myenhofer M, Navia B, Price RW. HTLV-III/LAV-like retrovirus particles in the brains of patients with AIDS encephalopathy. AIDS Res 1984-1985;1:447-454.

8. Tan K, Patel S, Gandhi N, Chow F, Rumbaugh J, Nath A. Burden of neuroinfectious diseases on the neurology service in a tertiary care center. Neurology 2008;71:1160-1166.

9. Singh G, Prabhakar S. The association between central nervous system (CNS) infections and epilepsy: epidemiological approaches and microbiological and epileptological perspectives. Epilepsia 2008;49:2-7.

10. Butcher J. Profile: Karen Roos: treating neuroinfections in Indiana. Lancet Neurol 2007;6:760. 


\section{Neurology}

\section{Emerging Subspecialties in Neurology: Neuroinfectious diseases \\ John J. Millichap and Leon G. Epstein \\ Neurology 2009;73; $14-\mathrm{e} 15$ \\ DOI 10.1212/WNL.0b013e3181af7a46}

\section{This information is current as of July 27, 2009}

\section{Updated Information \&}

Services

References

Citations

Permissions \& Licensing

Reprints including high resolution figures, can be found at: http://n.neurology.org/content/73/4/e14.full

This article cites 6 articles, 1 of which you can access for free at: http://n.neurology.org/content/73/4/e14.full\#ref-list-1

This article has been cited by 2 HighWire-hosted articles: http://n.neurology.org/content/73/4/e14.full\#\#otherarticles

Information about reproducing this article in parts (figures,tables) or in its entirety can be found online at:

http://www.neurology.org/about/about_the_journal\#permissions

Information about ordering reprints can be found online:

http://n.neurology.org/subscribers/advertise

Neurology ${ }^{\circledR}$ is the official journal of the American Academy of Neurology. Published continuously since 1951, it is now a weekly with 48 issues per year. Copyright. All rights reserved. Print ISSN: 0028-3878. Online ISSN: 1526-632X.

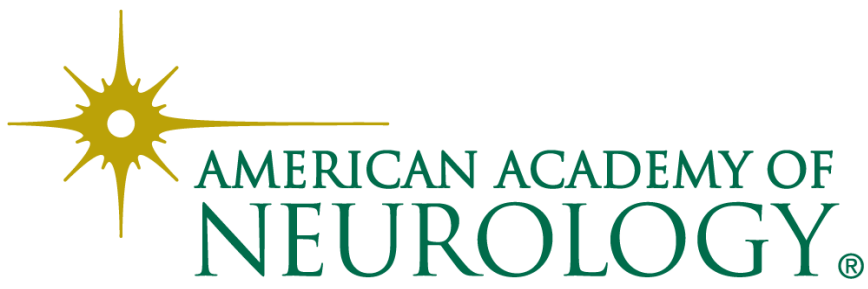

